\title{
Rethinking Postsecularism through Postcolonialism
}

\author{
Manav Ratti
}

Postsecularism has emerged in recent years as a set of theoretical interests, orientations, and questions across a range of fields, including political science, history, religious studies, philosophy, and literary studies. My focus in this article is on the possible relations between postsecularism and postcolonialism. I argue that postcolonialism can inflect postsecularism in ways similar to postcolonial literature's relation to western literature, a relation that seeks to uncompare and recompare universalisms, offering particular perspectives informed by historical and present-day violence. Comparatively speaking, whereas a western postsecularism can entail the rethinking of Christianity, an Indian postsecularism can entail the rethinking of a political formulation, of secularism as a state policy where the state assumes a principled distance from religion.

Manav Ratti is Associate Professor of English at Salisbury University, Maryland, USA and Visiting Fellow at the Humanities Research Centre at Australien National University.

"A straightforward narrative of progress from the religious to the secular," Talal Asad has argued, "is no longer acceptable" (Asad 2003, p. 1). Asad makes this assertion in Formations of the Secular, one of many works challenging the secularization thesis, that as societies become more modern - from agrarian to industrial to post-industrial - they become more secular, relying less on religion for a sense of security, and increasingly limiting religion to the private sphere. Asad's work offers an intriguing challenge, for it opens a theoretical space for rethinking the relations - political, philosophical, and otherwise - between the religious and the secular. Postsecularism has emerged in recent years as a set of theoretical interests, orientations, and questions across a range of fields, including political science, history, religious studies, philosophy, and literary studies. Postsecularism can serve as the name for the challenge to the secularization thesis. My focus in this article is on the possible relations between postsecularism and postcolonialism. As I have asked elsewhere (Ratti 2014a, 2014b), what does postsecularism mean for and within postcolonial nation-states? The ways in which the postcolonial can inflect the postsecular are theoretically similar to the relations between postcolonial literature and Western literature, and how the former can, according to Robert J. C. Young, uncompare and recompare the universal terms of the latter (Young 2013, p. 688). For Young, the postcolonial "domesticates the foreign, detranslating and retranslating the terms of its own forced comparatism, comparing where it was uncompared, uncomparing where it 
was invidiously compared, recomparing on its own terms" (ibid., p. 689). I focus in this article on postcolonial India, where the philosophical and religious secular of Western traditions becomes translated into politics as a state policy of secularism. Comparatively speaking, whereas a Western postsecularism can entail the rethinking of Christianity, an Indian postsecularism can entail the rethinking of a political formulation. In the latter case, such rethinking can occur fascinatingly in the forum of literary fiction, with its constitutively creative and facile reimagining of the abstractions and violence of the political, the historical, and the religious. I read in particular Amitav Ghosh's novel The Shadow Lines (1988), which contains a series of charged reflections on Partition and the East Pakistan genocide of 1964 .

To begin with postsecularism in the West, American society stands as an exception to the secularization thesis, given its combination of technological modernity and its large number of religious believers. This is perhaps among the factors that has led some American scholars to reflect upon postsecularism, as demonstrated in recent special issues of boundary 2 and American Literature. In the Spring 2013 special issue of boundary 2 on "Antinomies of the Postsecular," scholars with a range of interests - postcolonialism, queer theory, feminist theory, religion, philosophy - question and critique the presuppositions of postsecularism, such as the kinds of secularism (historical, philosophical, Christian, transcendental, political, among others) that it can assume. In the December 2014 special issue of American Literature on "After the Postsecular", Peter Coviello and Jared Hickman examine what they term postsecular 1, postsecular 2, and postsecular 3. For Coviello and Hickman, postsecular 1 is "the attempt to examine the historical past unburdened by a particular fantasy of the inevitable or necessary supersession of something called 'religion"" (Coviello and Hickman 2014, p. 646). It is here where Asad's challenge to the secularization thesis is particularly relevant. The epistemological and methodological "self-interrogation" that results from Coviello's and Hickman's conception of postsecular 1 is what they term postsecularism 2. The latter is marked by their question, "what habituated forms of thought, what orthodoxies major and minor, might get reconfigured from the ground up if imagined away from their anchoring in an implicitly secularizing framework?" (ibid., p. 647). This then leads to postsecularism 3, the ways in which re-thinking modernity and modern life might occur under a condition other than secularity, in place of which they propose globality. Of the above three senses of the postsecular, postsecularism 2 offers some of the most interesting overlaps within the Indian postcolonial context of state secularism. It is here that writers can reconfigure and reimagine some of the orthodoxies of nation and nationalism, and associated concepts like majoritarianism and minoritarianism. In my book The Postsecular Imagination, I examine literature as that site where writers can represent those orthodoxies while they endeavor, experimentally and riskily, to reimagine ethics of belief and coexistence within a religiously and ethnically pluralistic nation-state. Coviello and Hickman 
develop their conceptions of the postsecular with reference particularly to the American context and American literature.

\section{Postsecularism and Postcolonialism in India}

In this section, I examine the Indian context of postsecularism, to show the multiple faces of the secular and its postings within a global context. I want to begin by showing the differing conceptions of the term "secular" in Western contexts, since the Indian conception of secularism is influenced by the latter's Western genealogies.

The term "secular" has spatial and temporal dimensions, both with Christian inflections. It is derived from the Latin noun saeculum, which, according to the Oxford English Dictionary, can denote "age" or "generation," and, in Christian Latin, "the world." Each of these is the age, generation, or world to which humanity belongs, in opposition to the timelessness and world of God. "Secular" also referred to clergymen who lived outside the monastery, and therefore in the "world." Secular thus can designate the observable here-and-now, the visible world, a category distinct from religion, given the latter's ideas of the transcendental. Secularization in Western societies is the name for the various processes that separated institutionalized religion (for example, "the church") from the state, pushing religion into the private sphere; the term's oldest meaning is the state's expropriation of church property (Pecora 2006, p. 13). Secularization can be a specifically political term, denoting the relation between the political and the religious as a model for the organization of the state, and its ultimate relation with the nation. According to Vincent Pecora, "the practical link between modernization and secularization remains alive and well, and that the role of 'science' as an antidote to 'superstition' remains a significant part of what major Western social institutions - from the academies to the courts of law - consider the social good" (ibid., p. 17). Secularism is the name for the ideologies that emerge alongside or as a result of secularization, such as the ideology that people should confine their beliefs to what they can observe in the material world, or that to have a secular outlook, including the belief that state and religion should be separate, is to be modern, progressive, and rational. The word "secularism" was coined by the British theologian George Holyoake in 1851 to denote this confining of belief to the observable and material world.

In India, secularism has a specific sense as a state policy, and it is including in relation with this political sense of secularism that writers can imagine postsecular possibilities. As a postcolonial state policy, secularism has had to do enormous work over and across a nation that is highly diverse religiously and ethnically, one in which the state assumes (or sees itself assuming) a principled distance from all religious communities. (To say nothing of the imposition of the idea of "nation" onto India.) The idea and ideals of state secularism have deep resonances in India, 
becoming virtually synonymous with nationalism. This nationalism is important given the role of nationalism in anti-colonial struggles and postcolonial nationbuilding ambitions and pressures - protecting democracy and minority rights since India attained independence in 1947 from British rule. To its credit, the policy has been flexible in accommodating various religious and ethnic groups.

Despite the almost intuitive value of secularism as a nation-building state policy, even termed Nehruvian secularism for independent India's first Prime Minister Jawaharlal Nehru's commitment to a religiously neutral state, secularism in India has faced several crises. Not least among these crises is continuing violence, such as the massacre of Sikhs in 1984, the destruction of the Babri mosque in 1992 and the massacre of Muslims in Gujarat in 2002, in retaliation against a mob of Muslims burning a train containing Hindu pilgrims. Among other examples, 1985 saw an elderly Muslim woman, Shah Bano, successfully petition the Supreme Court for alimony. Conservative Muslim leaders argued that the state should not interfere in personal divorce laws established by and for religious communities. Prime Minister Rajeev Gandhi reversed the Supreme Court decision, a move perceived as not only placating Muslim voters but also neglecting women's rights. In 1989, the Mandal Commission recommended a significant increase in quotas in governmental jobs and educational institutions for members of scheduled castes and tribes, a decision that remains controversial in India, criticized by upper-caste Hindus. Also in 1989, armed conflict began in Kashmir, India's only Muslim-majority state, with insurgents seeking independence for Kashmir. Where the Indian state could have used diplomacy, its response in the 1990s was brutal, converting Kashmir into a conflict zone under the pretext of "protecting" secular nationalism.

In postcolonial nation-states, where the combination of religion and nationalism continues to be explosive and often violent, the postsecular does not represent a return to the kinds of realisms and imaginaries of religion that fuel violence. Similarly, the postsecular is neither a rejection of nor a substitute for political secularism. It does not signal a teleological end of secularism. Rather, it is an intimately negotiated term. Postsecularism advocates neither a religious, sectarian nation-state nor the uncritical espousal of religious belief at a personal level. Even my efforts at clarifying that the postsecular is not a return to the religious is at least a sign of the depth of Enlightenment imagination, that valorizes secularism as the sole bearer of rational progress. Peter van der Veer has argued that "the very distinction between religious and secular is a product of the Enlightenment that was used in orientalism to draw a sharp opposition between irrational, religious behavior of the Oriental and rational secularism, which enabled the westerner to rule the Oriental" (Breckenridge and van der Veer 1993, p. 39). Van der Veer's argument is certainly one of many, including Edward Said's foundational work on orientalism, which shows the politicization of the secularreligious divide across the colonizer and colonized, fixing both with immutable values, whether negative or positive. This politicization can result in a formation 
and opposition such as the "secular West" and the "non-secular non-West," a distinction I revisit at the end of this article. Given such a framework, the "postsecular" could be read catachrestically, as a productive misuse that might connote "return to the religious", but in fact denotes its negotiated relation with the secular.

For Indian writers, postsecularism can mark the exploration of alternatives to the crises of Indian state secularism while still holding onto the ideals and hardwon victories of that secularism, which include equality, democracy, fair and just legal representation, as well as rights across religious, ethnic, and minority communities. Postsecularism can also mark for these writers a creative search for (re)enchantment, of suffusing daily life with an ethics and vitality that can capture the generative intensities of religious faith and practice. This search is acutely aware of and resists the violence to which religious ideologies have been, and continue to be, vulnerable in colonial and postcolonial contexts. This is not to suggest that a postsecular search or philosophy characterizes religion as a whole by making, for example, an opposition between good religion (characterized as inspiring ethics) and bad religion (characterized as violence). Rather, a postsecular search or philosophy in a postcolonial context is similar to what Coviello and Hickman designate above as postsecularism 1. This postsecularism avoids a fantasy of what Coviello and Hickman term the "inevitable or necessary supersession" (Coviello and Hickman 2014, p. 646) of religion. Postcolonial postsecularism recognizes the enduring strength and reach of non-violent religious ethics (whether from orthodox or unorthodox religious beliefs), but is also critically aware of the violence to which some of those ethics (variously appropriated or misused) can be vulnerable. As I stated at the beginning of this article, within the domain of literature, writers can imagine and question "habituated forms of thought (...) orthodoxies major and minor" (ibid., p. 647) concerning secularism and religion, a process Coviello and Hickman term postsecularism 2. The postcolonialism of the postsecular is thus marked by the edge of the political, which includes memories of colonial violence, tragedies of postcolonial violence, the necessary ideals and protections of a democratic secular nation-state, and the compulsions of everyday ethical values.

By way of redressing the secular-religious divide, and infusing political secularism with some of the aspirational and affirmational ethics of religious thought, Indian scholars have offered several re-conceptions of secularism. Rajeev Bhargava has called for a "spiritualized, humanist" secularism (Bhargava 1995, p. 341). Rajeswari Sunder Rajan and Anuradha Needham, in their introduction to The Crises of Secularism in India, point to the existence of indigenous traditions other than state secularism, ones which can provide for both a practised tolerance and inspiring ethics:

there [. . .] continue to be significant traditions of popular tolerance, rationalism, secular humanism, and attitudes skeptical and ironic about religion, which are not reducible to 
the forms of elite or cosmopolitan secularism that are routinely attributed to the influence of Nehru and/or a deracinated modernity: in other words, what we might call an "indigenous" secularism, as belief and practice. It is fairly common to refer to Buddhism, Kabir, Akbar's Din Ilahi, Dara Sikoh, Ram Mohan Roy and Brahmo Samaj (reformist Hinduism), Ambedkar and Periyar in this context: a medley of names and influences that are broadly "secular" in spirit (Sunder Rajan and Needham 2007, p. 21).

Sunder Rajan and Needham list examples akin to "non-state secularisms," ones that are largely historical and which affirm values of tolerance, rationalism, and humanism without having the elitism of state secularism (this elitism meaning that it is imagined by class-, caste-, and gender-privileged policy makers, whose ideas do not have the reach and hold of an "indigenous" secularism). Sunder Rajan and Needham also offer contemporary examples of an indigenous secularism:

But it is not only the past, and not only the "folk," who give evidence of such a counterreligious strain. The work of a modern poet like Arun Kolatkar signals the profound resonance of a skepticism that is marked with compassion and even what we might call, paradoxically, faith. But there is much work yet to be done on establishing or forging the connections between this indigenous secularism which is part of the intellectual traditions of India and its ways of life, and official secularism as political ideology (ibid., p. 22).

Although writing in a different context, Aditya Nigam, by engaging with the work of Ashis Nandy, captures some of the flexibility afforded by imagining an "other" space through which to critique a state system. Nigam has argued that Ashis Nandy must imagine a "non-modern" space through which to critique the violence of the nation-state: "He [Ashis Nandy] is concerned with analysis and in that task he finds the imaginary space of the non-modern a useful reference point to highlight the violence of the modern nation-state and its drive towards homogenization" (Nigam 2006, p. 149). Nigam's astute observation of this move by Nandy toward an imaginary space, in this case that of the non-modern, shows a move similar to the creative ones enacted by writers as they reflect upon the nation-state and nationalism, and their associated violence, religious and otherwise. Such imagination and conceptualization are not purely imaginative, as if disconnected from having to politically and effectively address pragmatic, practical problems. For example, how do imagined solutions address the real problems of inequality, suffering, poverty, and other challenges to the goals of democracy? To invoke two ends of a state power spectrum, how could the language of the Indian parliament understand and recognize the voice of the destitute, dispossessed subaltern? What will be the time frame until a constitutional amendment can acknowledge and answer, fully and justly, such disempowerment? In the creative and flexible space of literature, such "amendments" can be placed alongside the originals, thus acting as two trajectories within a single representational frame. We can consider here Salman Rushdie's The Satanic 
Verses (1988). Rushdie interrogates the nature of religious belief and the pressures (and discriminations) of transnational migration by combining two narratives, intimately linking the historical prophet Muhammad with Rushdie's fictional character Mahound, the demonized version of the Indian character Saladin Chamcha, who relocates from Mumbai (then Bombay) to London. Such a rethinking of history resulted, of course, in charges of blasphemy, demonstrating at least the stakes at play when imagining an "other" space through which to critique a system, particularly when religion and politics are involved.

\section{Postsecularism and Indian Literature}

Among Indian literature, Amitav Ghosh's The Shadow Lines (1988) offers opportunities for reflecting upon how a writer can attempt to represent the devastating consequences of an historical and political crisis, namely, Partition. I focus on Partition here as it led to the "secularization" of the Indian state, as a nation-building project. As "secular India" then emerged, what were the histories that became necessary for the state to silence and overlook?

The Shadow Lines is set in India after Partition (1947), and is specifically set in the 1964 East Pakistan genocide, which culminated as revenge against the stealing of the Prophet Muhammad's hair from the Hazratbal Shrine in Srinagar, Kashmir. This genocide affected both East Pakistan and India, with religious majoritarianism combining with nationalism, resulting in violence. In East Pakistan, Muslims attacked Hindus (some of whom escaped to Calcutta), particularly in Dhaka, and Hindus attacked Muslims in Calcutta. Although Ghosh does not set his novel during Partition, two significant historical influences informed his writing of the novel. The first is that Ghosh himself had witnessed the riots of 1964. Secondly, the memory of the 1984 anti-Sikh pogrom in India, which I mentioned at the beginning of this article, was still very much alive for Ghosh. Both incidents mark a crisis of Indian secularism and the concomitant questions it raises about Indian nationalism. In the wake of Partition, how should we understand what constitutes secular India and what, in turn, constitutes Pakistan?

Ghosh vividly depicts the Hindu-Muslim riots of 1964 in Dhaka. The narrator's grandmother, Th'amma, travels to Dhaka to bring her uncle back to Calcutta. As their car makes its way through the city, a mob begins to form. Tridib's lover from England, May, is in the car with the grandmother, while Tridib and the grandmother's uncle follow in a rickshaw. When May sees the mob closing in on the rickshaw, she leaves the car to help Tridib, to the protest of the grandmother. But May is too late: Tridib and the uncle die. In her subsequent recounting of the experience to the narrator, May states,

I thought I'd killed him. I used to think: perhaps he wouldn't have got out of that car if I hadn't made him, if I'd understood what I was doing. I was safe you see - I could have 
gone right into that mob, and they wouldn't have touched me, an English memsahib, but he, he must have known he was going to die. For years I was arrogant enough to think I owed him his life. But I know now I didn't kill him; I couldn't have, if I'd wanted. He gave himself up; it was a sacrifice. I know I can't understand it, I know I mustn't try, for any real sacrifice is a mystery (Ghosh 1998, p. 251).

May has moved from guilt to "sacrifice" and "mystery," the former having religious connotations for her. This process of understanding is uniquely May's, and to emphasize the individuality of the search and questioning, Ghosh writes this passage from May's perspective, to show she can draw upon the language of Christianity to understand the murder of Tridib, who is Hindu. Tridib's death becomes an occasion through which Ghosh stresses national, gender, religious, and racial differences, but the register of ethics is translated by him into a religious register. The evening ends with May's inviting the narrator to stay the night. She had previously refused such a possibility, so the narrator now states, "I stayed, and when we lay in each others' arms quietly, in the night, I could tell that she was glad, and I was glad too, and grateful, for the glimpse she had given me of a final redemptive mystery" (ibid., p. 252). Ghosh again makes use of religious diction "redemption" - and situates it within the domain of affect, so that "love" has a certain healing quality, across nation, gender, religion, and race, and perhaps most importantly, at a time of tragic recollection. Redemption in this context is inspired by a religious context, perhaps inspired and/or learned by the narrator through his intimate contact with May and her Christianity. Yet such "redemption" emerges from and addresses thoroughly secular struggle and suffering: the political of the postcolonial, the politics of violence (and the violence of politics), and not any transcendentalism or escapism.

Suvir Kaul argues that the redemptive mystery that May enables the narrator to glimpse is "only partly sexual, and is in fact more her providing him with an emotional vocabulary that has allowed her, and will allow him, to think of Tridib's murder as 'sacrifice"' (Ghosh 1995, p. 277). Kaul's criticism captures the sense that signs still frame the experience for May, and an ethical frame is still very much present. Transferring the unspeakability and seeming incomprehensibility of the dilemma to a religious register - which contains its own notions of "love" (Christ's sacrifice, redemption) - gives some perspective and understanding, by providing both a form (language) and a content (sacrifice). The affective bond that develops between May and the narrator is one in spite of their national, gender, religious, and racial differences, especially in a novel committed to interrogating nationalism and its various expressions and consequences (cartography, communalism, Partition, secularism). Love and friendship, particularly across the real and imagined borders of nation, gender, religion, and race, can then emerge here as postsecular values. Shameem Black has argued that in Ghosh's fiction "homes and family in a postcolonial environment frequently provide alternatives to the nation and so his domestic spaces and relationships ironically share more with 
cosmopolitan perceptions, actions and ideals than they do with the practices of bounded communities" (Black 2006, p. 46; emphasis original). As an example of the limitations of what Black identifies as bounded communities, Ghosh deploys the rigid nationalism of Th'amma in order to deplore it, to show that it inheres in the "us versus them" logic of the 1964 genocides. Th'amma is a tragic figure, for as she travels to Dhaka, she realizes that there is no literal line on the land demarcating India and Pakistan. For us readers, this might function as a metaphor, an instructive metaphor pursued by Ghosh to demonstrate that the corollary "nationalization" of identity has equal, if not greater, devastating consequences as war and civil war.

In keeping with the title of his novel, Ghosh meditates on the nature of cartography and of naming, and on the capacity to speak of and represent the violence and trauma of Partition. Looking back over fifteen years, the unnamed narrator of the novel states: "Every word I write about those events of 1964 is the product of a struggle with silence. It is a struggle I am destined to lose - have already lost - for even after all these years I do not know where within me, in which corner of my world, this silence lies" (Ghosh 1998, p. 218). The silence is ineffable, resistant to representation, and in a sense "secular India" relies on such silence as it sanctions official narratives of the secular state and the corollary nation-state, leading us back to constructions of "secular India." Ghosh offers further reflections on the great difference between the representation of a map and the catastrophes peoples endure on the ground:

I was struck with wonder that there had really been a time, not so long ago, when people, sensible people, of good intention, had thought that all maps were the same, that there was a special enchantment in lines; I had to remind myself that they were not to be blamed for believing that there was something admirable in moving violence to the borders and dealing with it through science and factories, for that was the pattern of the world. They had drawn their borders, believing in that pattern, in the enchantment of lines, hoping perhaps that once they had etched their borders upon the map, the two bits of land would sail away from each other like the shifting tectonic plates of the prehistoric Gondwanaland (ibid., p. 233).

The two bits of land have of course not sailed away from each other, and the borders have not remained "etched". Instead, the lands have been closely intertwined, linked by violence and forced migration, both of which challenge the very stability of any fixed, secular nation-state. It is from this dissatisfaction with and indeed failure of the enchantment of the etched lines that the narrator reimagines those lines as the eponymous shadow lines. These shadow lines are fluid, unstable, and ephemeral lines that are not really "lines", but in intimate negotiation with the etched lines. We can read them as a metaphor of the relation between the secular and its post, with one not existing without the other. State secularism in India was born as an antidote to religious violence, echoing Ghosh's 
words above: "moving violence to the borders and dealing with it through science and factories". Here we can read "science and factories" as state rationalism, which the state expresses through state policies. The narrator also suggests above that two nations are two lands, ones that could sail away from one another. This line of thinking is similar to the Two Nation theory, which suggests that different religious groups (namely, Hindus and Muslims) require different physical territories, marked as nations. In the above passage, Ghosh also suggests that violence is a physical object, one that can be moved safely out of sight onto the margins of borders. We can induce from this the metaphor of violence and religion as physical objects that state secularism attempts to separate from one another (and, concomitantly, for the state to "distance" itself, in however principled a fashion, from religion). Yet the shadows of the lines challenge the lines themselves. They suggest new possibilities (of belief and belonging) that cannot be etched and fixed, and ones that are not disconnected from the etched lines themselves (hence the postsecular does not emerge or exist ex nihilo of the secular). Ghosh has stated: "writing about families is one way of not writing about the nation (or other restrictively imagined collectivities)" (Ghosh 2002, p. 147; emphasis original). The opposition I find interesting here is between family and restrictively imagined collectivities, suggesting that state secularism can be seen as creating an imaginatively restrictive collective. This criticism of state secularism resonates with the work of Ashis Nandy (1998), who has argued that such secularism contains an impoverished worldview in contrast to the imaginative conceptions of religious thought and religious traditions, which have their own embedded notions of interreligious tolerance.

In her book Limiting Secularism, Priya Kumar argues that Ghosh "undoes the polarizations of 'Indian' and 'Pakistani' by challenging the spatial imaginary of Indian and Pakistani nationalisms and their concomitant territorializations of identity" (Kumar 2008, p. 100). Central to this polarization of national identities is the idea of secularism, defined contrastively. As Kumar argues, "Only by undoing narratives of essentialized differences between a 'secular' India and a rabidly 'fundamentalist' Islamic Pakistan, as the narrator learns, can we begin to think about possibilities of multireligious coexistence in the subcontinent" (ibid., p. 105). It is precisely those possibilities of multireligious coexistence that postsecularism can imagine, even as a "non-space" that Ashis Nandy imagines, in and through which critiques of state secularism can exist. In his criticism of The Shadow Lines, Tuomas Huttunen argues that "Ghosh highlights imagination as a means of transcending hegemonic official representations" (Huttunen 2000, p. 33). I agree with Huttunen. Ghosh values the imagination (within his novel, and his novel itself as an act of the imagination) for at least its cognitive value, in giving peoples recognition of and distance from the hegemonies so deeply embedded in society and its politics and representations.

The postcolonial reimagining of the nation, particularly of its hegemonic representations, can serve as an example of Coviello's and Hickman's definition 
of postsecularism 2, as the reimagining of orthodoxies from, as it were, the ground up. This is no facile and recreational imagining: it is driven by violence, and here again is where the edge of the postcolonial can inform thoughtfulness about secularism.

That same violence can also characterize its opposite, peace. The narrator of The Shadow Lines offers the following reflection:

In fact, from the evidence of the newspapers, it is clear that once the riots had started both governments [India, East Pakistan] did everything they could to put a stop to them as quickly as possible. In this they were subject to a logic larger than themselves, for the madness of a riot is a pathological inversion, but also therefore a reminder, of that indivisible sanity that binds people to each other independently of their governments. And that prior, independent relationship is the natural enemy of government, for it is in the logic of states that to exist at all they must claim the monopoly of all relationship between peoples (Ghosh 1998, p. 230).

Among the distinctions that Ghosh develops above is between people and the state, with people bounded by an "indivisible sanity" that exists independently of the state. Ghosh also defines that binding by turning to its pathological opposite, violence, thus indirectly affirming that binding as a form of peace (a characterization supported by the positive valuation of it as "sanity"). Ghosh's description of state efforts at claiming a monopoly on all relationships between peoples can be parallel to "state secularism", which can be contrasted against what Sunder Rajan and Needham above describe as "indigenous secularism". It is in this criticism of state secularism that Ghosh's writing can be seen as postsecular. This is not to suggest, however, that any criticism of state secularism is postsecular. Instead, as I have mentioned above, Ghosh values non-state relationship as a "binding", and one that contains peace. It is that binding which suggests a kind of postsecular affirmation of other people and seeking peaceful coexistence with them ("binding sanity") that offers the positive ethical values of community, belonging, and amity.

This is not to suggest that any postsecular affirmation is final or stable. Rather, Ghosh's reflections on violence and ethics are experimental, representing a search rather than any easy answers or final solutions. For example, the narrator offers the below reflection on fear, in the context of a Hindu-Muslim riot:

It is a fear that comes of the knowledge that normalcy is utterly contingent, that the spaces that surround one, the streets that one inhabits, can become, suddenly and without warning, as hostile as a desert in a flash flood. It is this that sets apart the thousand million people who inhabit the subcontinent from the rest of the world-not language, not food, not music-it is the special quality of loneliness that grows out of the fear of the war between oneself and one's image in the mirror (ibid., p. 204).

The closing trope of the mirror foreshadows the narrator's following image of Calcutta and Dhaka: "[I]n Calcutta, [I] had only to look into the mirror to be in 
Dhaka; a moment when each city was the inverted image of the other, locked into an irreversible symmetry by the line that was to set us free - our looking-glass border" (ibid., p. 233). The contingency of normalcy (which I will read also as "peace") is what marks any postsecular affirmative values as themselves contingent, momentary, and tenuous. This knowledge of contingency is postcolonial: it is from a historically postcolonial context, and it is skeptical of any certitudes, knowing that power is always present and negotiations with that power (across religions, cities, and nations) are never perfectly stable or equitable. Anshuman Mondal argues that the image across the border "is not an Other but rather the Self, the divided Indian Self. It is this Self across the border that renders secular Indian nationalism a failure since it has not united the Self" (Mondal 2006, p. 28). Mondal echoes here my argument that violence stands as one of the greatest signs of the failures of Indian secularism (and, by extension, Indian secular nationalism). Where Mondal argues for disunity as a sign of failure (and, inversely, for unity as a sign of success), we can use a postsecular critical vocabulary to theorize this notion of failure and success. Ghosh's image of the essential sameness across oneself and the other (whether that other belongs to a different religion, ethnicity, or nation, or all four) takes the tentative affirmational risk of humanism. I call this a risk because, although the narrator knows any such humanism is vulnerable to violence and suffused with fear, Ghosh nonetheless inserts this humanism, however minimally, in the text.

As a brief comparison with Ghosh's novel, we can consider Shauna Singh Baldwin's novel What the Body Remembers (2000), which depicts the events immediately preceding Partition. Narrated from a Sikh perspective against the more dominant Hindu and Muslim responses to Partition, the novel questions the very distinction between "India" and "Pakistan". I have argued that if "the nations that are 'Pakistan' and 'India' are secular entities, enacted through a secular distinction, then What the Body Remembers is postsecular in showing the crises and injustices resulting from such a separation. Violence in this novel becomes the marker of the inadequacies of the national "border"' (2014a, p. 120). In his novel Train to Pakistan (1956), set in a small Indian village in the immediate aftermath of Partition, Khushwant Singh takes a humanistic approach in challenging the distinction between "India" and "Pakistan". He begins the novel by showing peaceful coexistence among Sikhs and Muslims in the village, suggesting that loyalty to one's village is stronger than loyalty to one's religion. As the novel progresses, some Sikh men succumb to anti-Muslim hate and plan to take the lives of Muslim passengers on a train headed to Pakistan. Their plan, however, is foiled by another Sikh man, who is in love with a Muslim woman from the village. Singh thus gestures toward "love" as a challenge to not only religious nationalism but also, paradoxically in the case of India, state secularism.

The posting of the secular is not only that of philosophical secularism - in the wake of which posting, there could be a turn to discourses of spirituality - but also that of political secularism. In a postcolonial nation-state like India, such political 
secularism has considerable significance, extending to minority rights and freedom of religion. This wide-reaching significance will inevitably fall short of adequate recognitions and redresses, and it is here that the domain of literature including the reading I have undertaken in this article of Amitav Ghosh's The Shadow Lines - can imagine possibilities and models of peaceful coexistence and communal harmony. By "postsecular" in postcolonial contexts, I do not mean the wholesale abandonment of the hard-won struggles of the secularism that aspires toward democratic and legal recognition of religious difference and, again, minority rights. In the case of India, such recognition continues to be important for ensuring democracy. Postsecularism is thus a philosophy or search, which can be enacted through literature. Consequently, I do not mean to burden the literary imagination with great expectations, as if it were unremoved from the very real forces of history and politics. Literature is not religion. Literature is not secularism. Of course, literature itself is shaped by the forces of secularism and religion, as my above reading of The Shadow Lines demonstrates, and as dramatically and tragically demonstrated by the fatwa against Salman Rushdie. I see the postsecular literary imagination as a forum for imagining, exploring, searching for, and experimenting with - in risky, individualistic, tentative ways solutions to enduring political, secular, and religious challenges, including those of postcolonialism.

In the American literary context, John McClure has deployed postsecularism in focusing on the postmodern fiction of writers such as Thomas Pynchon, Don DeLillo, and Ishmael Reed. For McClure, postsecular texts are shaped by spiritual concerns, by which he means that they make room for the magical, the miraculous, and for religious categories (McClure 1995, p. 143). These texts' postmodern features - which theorists such as Fredric Jameson and Jean-Francois Lyotard have identified, including "assaults on realism" (ibid.), playfulness, and experiments with the sublime - can be understood, argues McClure, as resacralization (ibid., p. 144). McClure defines resacralization as "spiritually inflected resistance to conventionally secular constructions of reality" (ibid., p. 143), and as privileging "non-secular practices and constructions of the real" (ibid., p. 150).

What emerges in McClure's postsecular analyses is a broad distinction between the secular and the spiritual. This is not to suggest, however, that such spirituality is naïve escapism or other-worldliness. McClure argues: "the spirituality of these and other contemporary texts represents itself, then, not as an alternative to worldliness but as a life-affirming and profoundly worldly alternative to the psychologically alienating and ecologically destructive pseudo-worldliness of secular rationality" (ibid., p. 157). Such worldliness consists of "compassionate identification with a creaturely community that suffers, enjoys, and endures" (ibid.). It is here where we can find an interesting convergence with postcolonial postsecularism, where such a postsecularism is not an abandonment of secular concerns and commitments. Nor can it be a turn, in the postcolonial context, to the sense of "religion" that provokes violence, the latter particularly attempted to be 
redressed by a secular state policy. The postsecular also cannot offer the teleologies and certainties that "religion" can postulate because, again, postcolonial legacies and conflicts show it is such teleology and certainty that can provoke and sustain violence. For the postcolonial writer, therefore, any postsecular affirmation is tentative, a search, a risky exploration, a gesture. There are no facile "answers", and here again is a parallel with McClure's postmodern postsecular. McClure argues that "Pynchon returns us to the domain of sacred experiences and doctrines, then, but not to set us down in some safe zone of putative certainty" (ibid., p. 153). Thus, while postmodern fiction can decenter grand narratives, it does not recentre them, just as Pynchon's and DeLillo's spiritual searches are marked by quests "to reach and to resist grasping" (ibid.). That resistance shows the humility of recognizing that one cannot have complete knowledge. For the postcolonial writer, such humility stems from vulnerability: to power, to colonial legacies, to present inequities and to the easily manifest realities of violence.

McClure invokes postcolonial theorists Homi Bhabha and Ashis Nandy to argue for rethinking postmodernism as constituted by "voices [that] challenge the hegemony of secular rationalist discourse" (ibid., p. 148), and thus expand the range of postmodern texts to include works from Latin American, African American, and Native American writers. The intersection here with postcolonialism is through the route of power, in recognizing that postcolonial theorists can offer insights into practices of institutional and epistemological exclusion and marginalization. One possible connotation (and I am not attributing this to McClure) of such an expanded definition of postmodern texts is the equation of the non-West with "religion" or "non-secularism". Since the 1995 publication of McClure's article, the world has of course become a different place, not the least because of the rise of social media and of international religious violence driven by terrorism, provoking rethinking of the distinction between the "secular West" and the "non-secular non-West". By turning to diasporic postcolonial writers with influences from both, say, India and the US - as in the case of Amitav Ghosh and Salman Rushdie - we can examine how there might be at least a double posting of the secular, of both philosophical secularism and postcolonial state secularism. The postsecularism that such writers reach and gesture toward, explore, and imagine is one that might decenter some of the most sacred ideas and practices of majoritarianism, minoritarianism, multiculturalism, nationalism, faith, and religion, among others.

\section{References}

Asad, Talal: Formations of the Secular: Christianity, Islam and Modernity. Stanford 2003. Bhargava, Rajeev: "Religious and Secular Identities," in: Baxi, Upendra / Parekh, Bhikhu. Crisis and Change in Contemporary India. New Delhi 1995. 
Black, Shameem: “Cosmopolitanism at Home: Amitav Ghosh's The Shadow Lines", in: Journal of Commonwealth Literature (41.3) 2006, pp. 45-65.

Coviello, Peter / Hickman, Jared: "Introduction: After the Postsecular", in: American Literature (86.4) 2014, pp. 645-654.

Ghosh, Amitav: The Shadow Lines. New Delhi 1995 (Oxford University Press).

Id.: The Shadow Lines. New Delhi 1998 (Ravi Dayal Publisher).

Ghosh, Amitav / Chakraborty Dipesh: "A Correspondence on Provincializing Europe", in: Radical History Review (83) 2002, pp. 146-172.

Huttunen, Tuomas: "Narration and Silence in the Works of Amitav Ghosh", in: Journal of Postcolonial Writing (38:2) 2000, pp. 28-43.

Kaul, Suvir: "Separation Anxiety: Growing up Inter/National in The Shadow Lines", in: Ghosh, Amitav: The Shadow Lines. New Delhi 1995.

Kumar, Priya: Limiting Secularism: The Ethics of Coexistence in Indian Literature and Film. Minnesota 2008.

McClure, John: "Postmodern/Post-Secular: Contemporary Fiction and Spirituality", in: Modern Fiction Studies (41.1) 1995, pp. 141-163.

Mondal, Anshuman: "Allegories of Identity: 'Postmodern' Anxiety and 'Postcolonial' Ambivalence in Amitav Ghosh's In An Antique Land and The Shadow Lines", in: Journal of Commonwealth Literature (38.3) 2006, pp. 19-36.

Nandy, Ashis: "The Politics of Secularism and the Recovery of Religious Tolerance", in: Rajeev Bhargava (ed.). Secularism and Its Critics. Oxford 1998.

Nigam, Aditya: The Insurrection of Little Selves: The Crisis of Secular-Nationalism in India. New Delhi 2006.

Pecora, Vincent: Secularization and Cultural Criticism: Religion, Nation, and Modernity. Chicago - London 2006.

Ratti, Manav: The Postsecular Imagination: Postcolonialism, Religion, and Literature. London-New York 2014a.

Id.: "The Postsecular and the Postcolonial", in: Mason, Emma (ed.) Reading the Abrahamic Faiths: Rethinking Religion and Literature. London 2014b.

Sunder Rajan, Rajeswari /Needham, Anuradha: The Crisis of Secularism in India. Durham, North Carolina 2007.

Young, Robert J. C.: “The Postcolonial Comparative”, in: PMLA (128.3) 2013, pp. 683 689. 